\title{
Oblique collision and deformation partitioning in the SW Iberian Variscides
}

\author{
Irene Pérez-Cáceres, José Fernando Simancas, David Martínez Poyatos, Antonio Azor, and \\ Francisco González Lodeiro
}

Departamento de Geodinámica, Facultad de Ciencias, Universidad de Granada, Campus de Fuentenueva s/n, 18071 Granada, Spain

Correspondence to: Irene Pérez-Cáceres (perezcaceres@ugr.es)

Received: 27 November 2015 - Published in Solid Earth Discuss.: 9 December 2015

Revised: 27 April 2016 - Accepted: 9 May 2016 - Published: 30 May 2016

\begin{abstract}
Different transpressional scenarios have been proposed to relate kinematics and complex deformation patterns. We apply the most suitable of them to the Variscan orogeny in SW Iberia, which is characterized by a number of successive left-lateral transpressional structures developed in the Devonian to Carboniferous period. These structures resulted from the oblique convergence between three continental terranes (Central Iberian Zone, Ossa-Morena Zone and South Portuguese Zone), whose amalgamation gave way to both intense shearing at the suture-like contacts and transpressional deformation of the continental pieces in-between, thus showing strain partitioning in space and time. We have quantified the kinematics of the collisional convergence by using the available data on folding, shearing and faulting patterns, as well as tectonic fabrics and finite strain measurements. Given the uncertainties regarding the data and the boundary conditions modeled, our results must be considered as a semiquantitative approximation to the issue, though very significant from a regional point of view. The total collisional convergence surpasses $1000 \mathrm{~km}$, most of them corresponding to left-lateral displacement parallel to terrane boundaries. The average vector of convergence is oriented $\mathrm{E}-\mathrm{W}$ (present-day coordinates), thus reasserting the left-lateral oblique collision in SW Iberia, in contrast with the dextral component that prevailed elsewhere in the Variscan orogen. This particular kinematics of SW Iberia is understood in the context of an Avalonian plate salient currently represented by the South Portuguese Zone.
\end{abstract}

\section{Introduction}

Oblique convergence/divergence between lithospheric plates or continental blocks are common tectonic scenarios, usually named transpression/transtension (Harland, 1971; Sanderson and Marchini, 1984). Strain resulting from transpression is usually modeled as a combination of a three-dimensional coaxial component and an orthogonal simple shear component (Tikoff and Fossen, 1999). Less frequently, oblique convergence has been modeled as a combination of two simple shears, with lateral (wrenching) and orthogonal (thrusting) kinematics (Ellis and Watkinson, 1988). The oblique convergence/divergence that characterizes transpression usually involves deformation partitioning into thin bands concentrating lateral displacements and broader domains concentrating orthogonal displacements (e.g., Holdsworth and Strachan, 1991; Tikoff and Teyssier, 1994).

Following the works by Sanderson and Marchini (1984) and Fossen and Tikoff (1993), many increasingly sophisticated models have been developed to analyze high-strain transpressional zones. A number of boundary conditions have been introduced, such as lateral extrusion (Dias and Ribeiro, 1994; Jones et al., 1997; Teyssier and Tikoff, 1999), inclined walls (Jones et al., 2004), oblique extrusion and/or oblique simple shear (Jiang and Williams, 1998; Lin et al., 1998; Czeck and Hudleston, 2003, 2004; Fernández and Díaz-Azpiroz, 2009), no slip at the boundaries with undeformed walls (Dutton, 1997; Robin and Cruden, 1994) and migrating boundaries (Jiang, 2007).

SW Iberia (Fig. 1) geological architecture resulted from a complex transpressional evolution during the Variscan collision in the Devonian to Carboniferous period (e.g., Pérez- 
Cáceres et al., 2015). This evolution involved the oblique convergence between three continental terranes, namely, from north to south, the Central Iberian Zone (CIZ), the Ossa-Morena Zone (OMZ) and the South Portuguese Zone (SPZ). These terranes show transpressional left-lateral kinematics with deformation partitioning (Burg et al., 1981; Matte, 1991; Crespo-Blanc, 1992; Azor, 1994; Quesada et al., 1994; Expósito et al., 2002; Silva and Pereira, 2004; Ponce et al., 2012), thus contrasting with the dextral component that characterizes most of the Variscan collision in other regions of the orogen (e.g., Shelley and Bossière, 2000).

This work aims to describe and approximately quantify the Variscan transpressional deformation in SW Iberia. We are particularly interested in evaluating the left-lateral component of the transpressional deformation, in order to achieve an approximate image of the relative position of the terranes involved in this oblique collision. To do so, the use of sophisticated transpressional models might not be justified, since these models demand stringent geological data hardly available for a large-scale tectonic analysis (e.g., Jiang and Williams, 1998; Fernández et al., 2013). For this reason, simple monoclinic-flow models (Dewey et al., 1999) and other approximate tools may yield regionally valuable approximations.

\section{Variscan events in SW Iberia}

The Variscan/Alleghanian orogeny resulted from the closure of the Rheic Ocean that separated Avalonia and Gondwana during the Ordovician to Devonian period (Fig. 1a). The subsequent collision amalgamated these two continents along with intervening minor oceanic realms and micro-continents in-between (e.g., Matte, 1991, 2001; Murphy and Nance, 1991; Franke, 2000; Stampfli and Borel, 2002).

Prior to the Rheic Ocean formation, the arc-type Cadomian orogeny variedly overprinted the northern margin of Gondwana during the Ediacaran (e.g., Linnemann et al., 2014). In Iberia, this orogeny resulted in the development of thick synorogenic arc-related basins (e.g., in the CIZ; Rodríguez-Alonso et al., 2004) and calc-alkaline arc-related magmatism that concentrated in the OMZ and southernmost CIZ (Sánchez Carretero et al., 1990; Pin et al., 2002; Bandrés et al., 2004; Simancas et al., 2004).

As for the Variscan evolution, the boundaries between the CIZ, OMZ and SPZ terranes are considered as sutures (Fig. 1). The CIZ is a continental domain that formed part of northern Gondwana, while the OMZ is commonly interpreted as a continental piece that rifted (and drifted to some extent) from Gondwana (i.e., the CIZ) in the early Paleozoic (Matte, 2001; Robardet, 2002). Subsequent collision between these two terranes resulted in the suture unit known as Badajoz-Córdoba Shear Zone (BCSZ) or Central Unit (Fig. 1c) (Burg et al., 1981; Azor et al., 1994). The BCSZ includes some early Paleozoic amphibolites (Ordóñez Casado,
1998) with a geochemical signature akin to oceanic crust (Gómez-Pugnaire et al., 2003). A first collisional stage is attested by eclogite relics in the BCSZ (1.6-1.7 GPa; Abalos et al., 1991; Azor, 1994; López Sánchez-Vizcaíno et al., 2003) and large-scale Devonian recumbent folds and thrusts in the colliding blocks (OMZ and southern CIZ; Simancas et al., 2001, and references therein). The eclogites were exhumed during the subsequent, latest Devonian to Early-Middle Mississippian intense ductile left-lateral shearing that characterizes the BCSZ (Burg et al., 1981), coeval to normal faulting, basin development and mafic magmatism at both sides of the BCSZ. Renewed Pennsylvanian compression is attested by upright folds and left-lateral strike-slip faults. Overall, the CIZ-OMZ boundary is interpreted as a Gondwana-related second-order suture of the Variscan orogen (e.g., Simancas et al., 2005).

The OMZ-SPZ boundary (Fig. 1) has been classically interpreted as the suture of the Rheic Ocean. This boundary is constituted by three units (Fig. 1c): (i) the BejaAcebuches (BA hereafter) unit, metamorphosed mafic and ultramafic rocks that crop out all along this major contact (Munhá et al., 1986; Crespo-Blanc, 1991; Fonseca and Ribeiro, 1993; Quesada et al., 1994; Castro et al., 1996; Azor et al., 2008); (ii) the Pulo do Lobo unit, a low-grade metasedimentary unit with minor mid-ocean-ridge basalt (MORB)like metabasalts (Eden and Andrews, 1990; Silva et al., 1990; Eden, 1991; Braid et al., 2010; Dahn et al., 2014); and (iii) the allochthonous Cubito-Moura unit, which contains highpressure and MORB-like rocks emplaced onto the OMZ border (Fonseca et al., 1999; Araújo et al., 2005; Ponce et al., 2012). Recent work including new structural and radiometric data has improved our knowledge on the significance of the Pulo do Lobo Unit, as well as on the geometry and timing of deformations affecting the OMZ-SPZ suture (Pérez-Cáceres et al., 2015), which is now viewed as a Rheic cryptic suture, blurred by Carboniferous tectonothermal imprints. Thus, the envisaged evolution of the OMZ-SPZ boundary can be summarized as follows (Fig. 2).

(i) Following Rheic Ocean consumption in the Devonian period, the southern border of the OMZ partially subducted (high-pressure rocks). Some of the subducted rocks were later scrapped off along with Rheic Ocean rocks and emplaced (the allochthonous Cubito-Moura unit) onto the southern OMZ (Araújo et al., 2005; Fig. 2a). The kinematics of emplacement, recorded in an early stretching lineation, is top-to-the-ENE, which corresponds to a tectonic regime of oblique left-lateral convergence (Ponce et al., 2012).

(ii) An Early-Middle Mississippian transtensional event temporarily interrupted the convergence and created a very narrow aisle of oceanic-like crust (actually represented by the BA unit) just at the OMZ-SPZ boundary (Fig. 2b) (Azor et al., 2008). Moreover, ca. $340 \mathrm{Ma}$ 

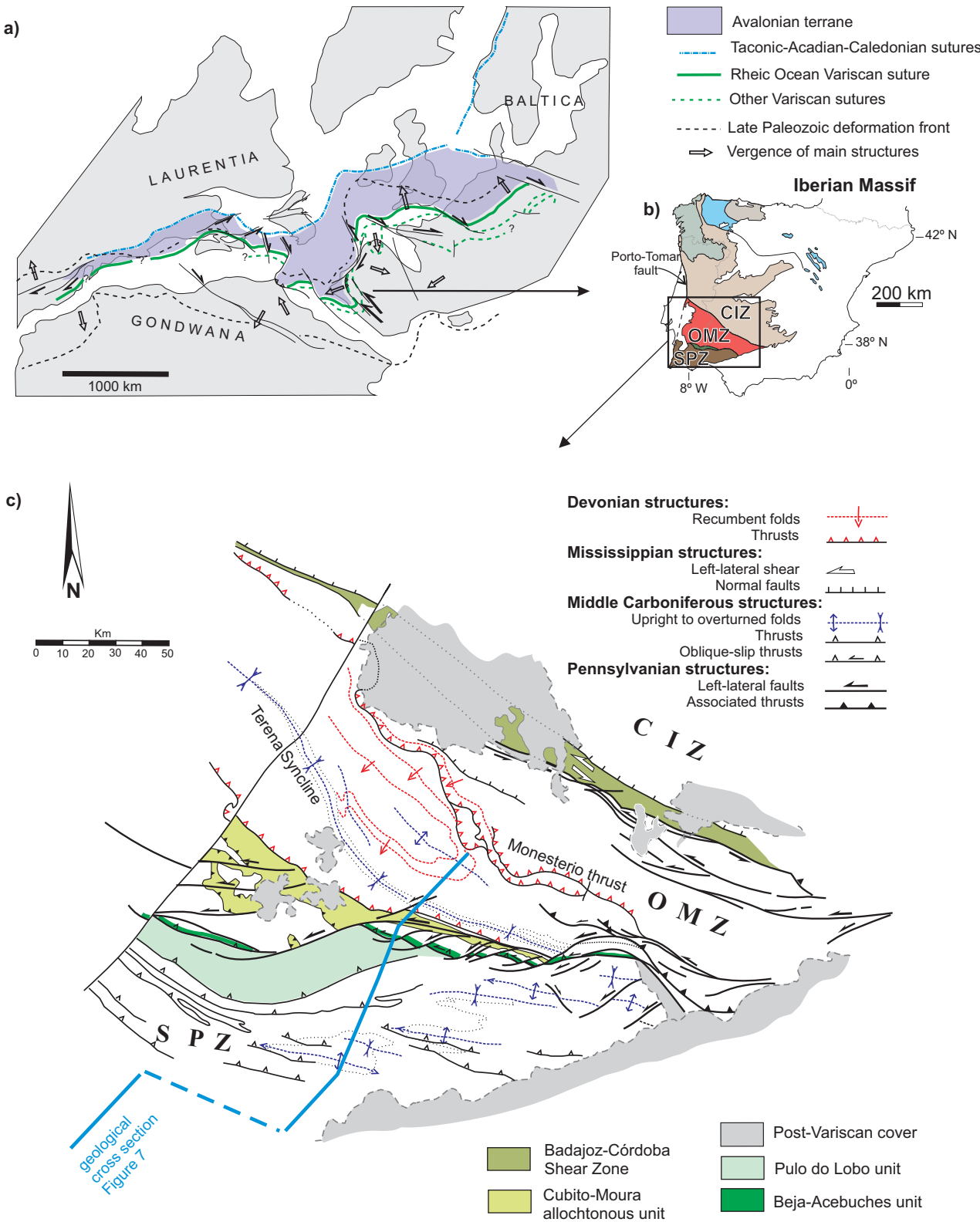

Figure 1. (a) Reconstruction of the Variscan-Alleghanian orogen at the end of the Carboniferous simplified from Simancas et al. (2005). The Avalonian continental piece and the inferred Rheic Ocean and other second-order Variscan sutures are depicted. The SW Iberian left-lateral shear sutures are highlighted. (b) Geological subdivision of the Iberian Massif. CIZ: Central Iberian Zone; OMZ: Ossa-Morena Zone; SPZ: South Portuguese Zone. (c) Structural map of the SW Iberia showing the main units and the different Devonian and Carboniferous structures. The location of the cross section in Fig. 7 is indicated.

mafic and acid magmatism intruded/extruded at both sides of the oceanic strip.

(iii) Convergence was resumed immediately, giving way to northwards obduction of the BA unit, as well as northverging folds and tectonic imbrications in the Pulo do Lobo unit (Pérez-Cáceres et al., 2015; Fig. 2c).

(iv) Subsequently, south-vergent transpressional structures developed (Fig. 2d). The BA unit was folded syn- chronously with left-lateral high-temperature shearing (Pérez-Cáceres et al., 2015), which evolved to greenschist facies conditions and concentrated in the southern part of the unit (Crespo-Blanc and Orozco, 1988; Quesada et al., 1994). Oblique convergence propagated southward across the SPZ in the Pennsylvanian. In the late Variscan orogeny period, left-lateral displacements newly focused on the OMZ-SPZ boundary as brittle strike-slip faults. 


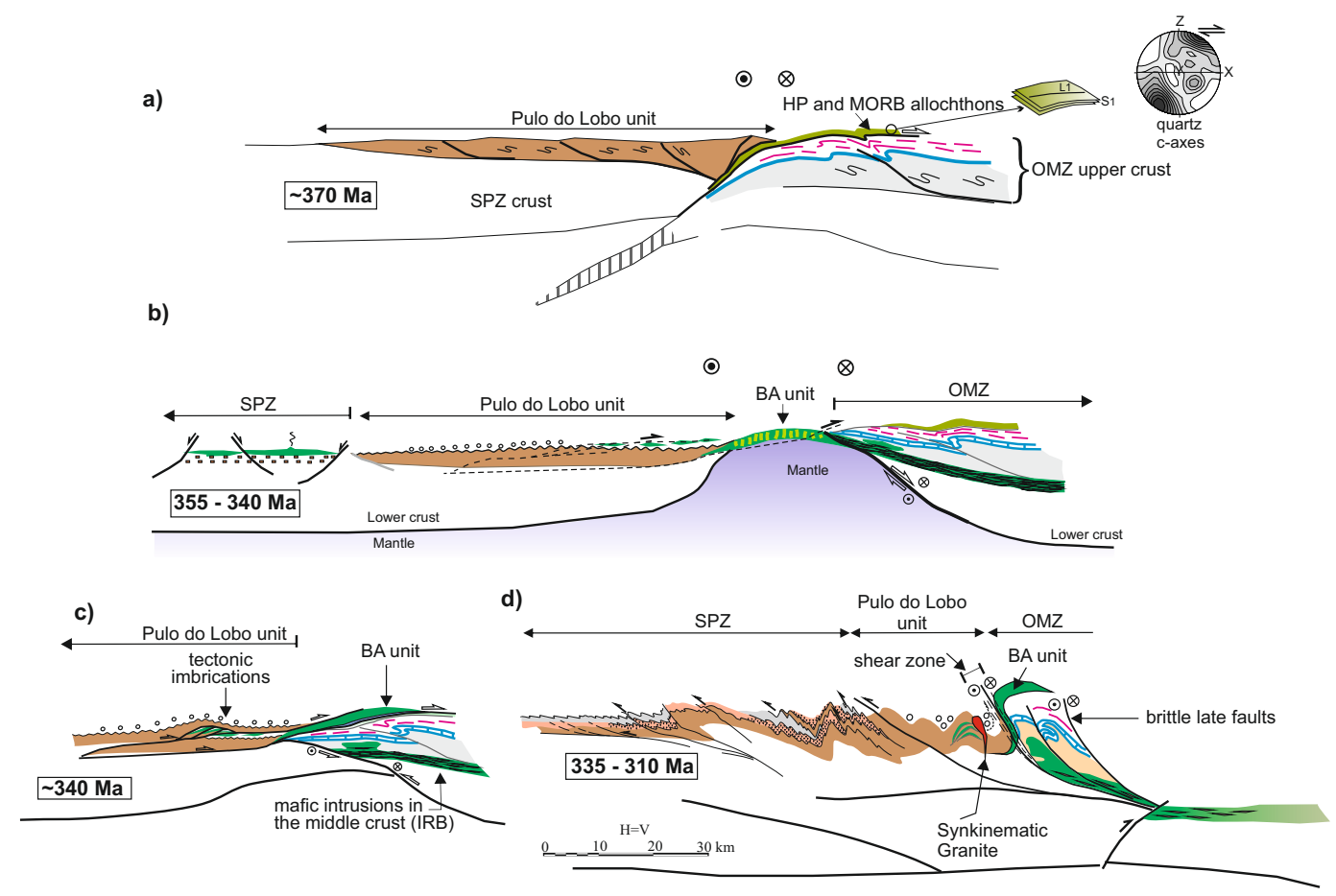

Figure 2. Evolutionary model for the OMZ-SPZ boundary from the Middle-Late Devonian to the Pennsylvanian proposed by Pérez-Cáceres et al. (2015). (a) Closing of the Rheic Ocean and Late Devonian collision. (b) Early Carboniferous intracollisional transtensional stage mainly represented by the metamafic BA unit. (c) Carboniferous renewed oblique collision, producing the obduction of the BA unit onto the OMZ. (d) High- to low-temperature folding and shearing of the BA unit and southwards propagation of the deformation. Notice that the left-lateral component of displacements, indicated by standard symbols, cannot be included in these cross sections.

\section{Deformation partitioning in SW Iberia}

One of the most striking features of SW Iberia is the partitioning of bulk regional deformation into four well-defined domains, namely, from north to south: (i) CIZ-OMZ boundary, (ii) OMZ terrane, (iii) OMZ-SPZ boundary, and (iv) SPZ terrane (Fig. 1c).

The CIZ-OMZ boundary, marked by the BCSZ, shows a prominent $S$ - $L$ fabric with occasional $L$-type tectonites. The stretching lineation is subhorizontal and kinematic indicators indicate left-lateral displacement (Burg et al., 1981; Azor et al., 1994). Moreover left-lateral strike-slip faults developed in the Pennsylvanian period around this boundary. The OMZ records Devonian and Carboniferous compressional deformation events separated by a singular Mississippian transtensional stage. Both Devonian and Carboniferous folds and thrusts trend obliquely to the OMZ boundaries, suggesting a transpressional setting (Expósito, 2000; Expósito et al., 2002). The OMZ-SPZ boundary is underlined by the narrow belt of the BA unit, affected by leftlateral ductile shearing and strike-slip brittle faults (Bard, 1977; Crespo-Blanc and Orozco, 1988; Quesada et al., 1994; Díaz-Azpiroz and Fernández, 2005). Finally, the SPZ is a Carboniferous south-vergent fold-and-thrust belt (Oliveira, 1990; Simancas et al., 2003) with axial traces slightly oblique to the northern boundary of the terrane, thus featuring transpressional deformation (Simancas, 1986).

The brief description advanced above illustrates that ductile and brittle sinistral strike-slip shear bands characterize the CIZ-OMZ and OMZ-SPZ boundaries, while deformation inside the OMZ and SPZ terranes includes a significant component of orthogonal shortening. Deformation partitioning such as that displayed in SW Iberia is believed to be favored by low angles of plate convergence (Teyssier et al., 1995), but a more comprehensible kinematic analysis can be gained by analyzing deformation data in more detail. Our description will proceed from north to south, except for the displacements associated with late Variscan brittle faulting that will be considered jointly at the end.

\section{Ductile shearing at the CIZ-OMZ boundary}

The BCSZ is a NW-SE-trending band of highly deformed schists, gneisses, migmatites and amphibolites that constitutes the CIZ-OMZ boundary (Fig. 1c). It exhibits, consistently along $200 \mathrm{~km}$ of visible outcrop, an intense mylonitic $S$ - $L$ fabric (locally $L$ fabric) with subhorizontal stretching lineation (pitch less than $15^{\circ}$ ) and left-lateral kinematics (Burg et al., 1981; Azor et al., 1994). The age of the duc- 

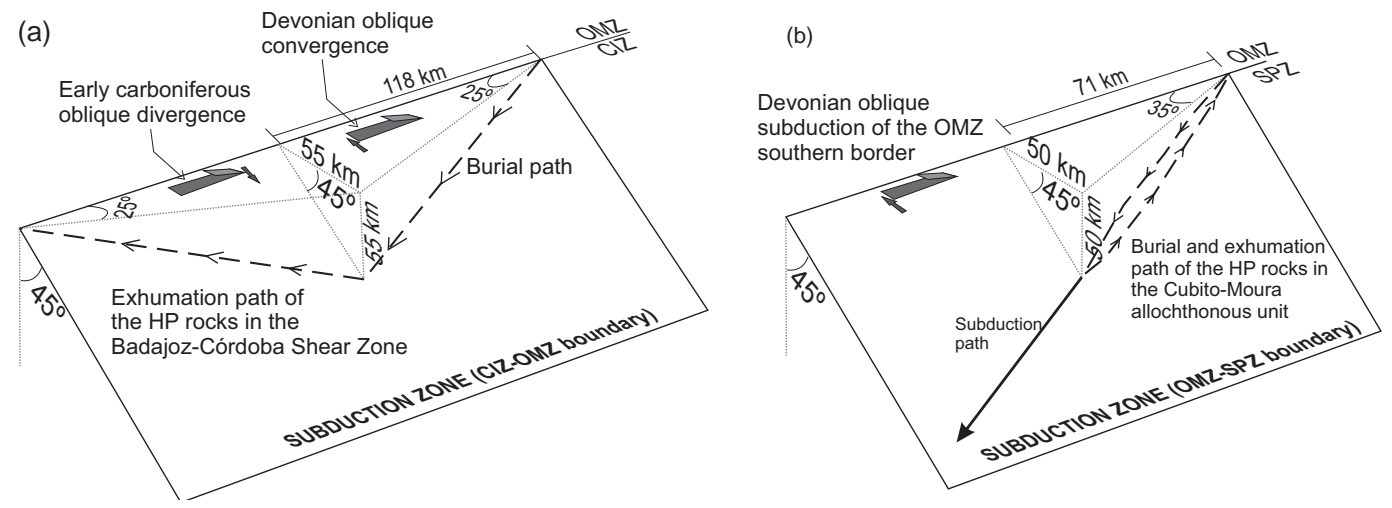

Figure 3. Simple models of burial and exhumation for the high-pressure rocks cropping out at the two collisional boundaries of the OMZ. (a) CIZ-OMZ boundary. (b) OMZ-SPZ boundary. See text for more explanations.

tile shearing in the BCSZ ranges from at least latest Devonian to Middle Mississippian, according to different, not fully consistent, metamorphic geochronological data: 340 330 (Ar / Ar on biotite) (Blatrix and Burg, 1981), 370$360 \mathrm{Ma}$ (Ar / Ar on hornblende), 340-330 (Ar / Ar on muscovite) (Quesada and Dallmeyer, 1994) and ca. 340 (U / Pb on zircon) (Ordóñez Casado, 1998; Pereira et al., 2010). In any case, textural evidence indicates that high-pressure metamorphism took place prior to that shearing, i.e., before the Late Devonian period. South of the BCSZ, the OMZ depicts pro-wedge Devonian SW-vergent folds and thrusts (Expósito et al., 2002); to the north, the southernmost CIZ shows conjugate retro-wedge NE-vergent Devonian folds (Martínez Poyatos, 1997; Simancas et al., 2001; Expósito et al., 2002).

The kinematics of the BCSZ is analyzed here in two different ways: (i) considering the recorded strain, in the light of the simple shear model; and (ii) considering a more complete, though poorly constrained, subduction-exhumation path.

(i) Simple shear in the BCSZ: the mylonitic fabric with subhorizontal stretching lineation, consistent all along $200 \mathrm{~km}$ of outcrop (Burg et al., 1981; Azor et al., 1994), suggests approximate monoclinic strain (Lin et al., 1998), and can be approximately analyzed by means of the strike-slip simple shear model. The finite strain in this shear zone can be roughly assessed from the very elongated shape of some orthogneissic bodies located inside the BCSZ (e.g., the Ribera del Fresno orthogneiss), which suggests $X / Z \approx 11$ and $\gamma \approx 3$ assuming simple shear. However, this is a rather conservative estimation, since these bodies are relatively rigid strain markers surrounded by schists. For this reason, we will take $\gamma=4$ in the following calculation. The thickness of the BCSZ is another important parameter to take into account; the maximum outcropping thickness is $15 \mathrm{~km}$, but the original one was probably greater $(20-25 \mathrm{~km})$ because late Variscan brittle faults abruptly cut and bound the ductile shear zone, as seen on the geological map (Fig. 1c) and in the seismic image (Simancas et al., 2003). Thus, considering an original thickness of $20-25 \mathrm{~km}$ and a mean shear strain $\gamma=4$, a tentative left-lateral displacement of $80-100 \mathrm{~km}$ results. The transpression model of inclined walls (Jones et al., 2004) is another way to examine the BCSZ, since this crustal-scale shear zone has been seismically imaged dipping to the NE (Simancas et al., 2003). According to this transpression model, the subhorizontal stretching lineation would be only compatible with an angle of convergence less than $10^{\circ}$; i.e., the simple shear component should have been extremely dominant. Thus, the left-lateral displacement derived from this model does not differ significantly from the one obtained with the strike-slip simple shear model.

(ii) Two simple shear events during a subductionexhumation path: besides left-lateral displacement, the movement between the CIZ and the OMZ must have included a dip-slip component of shearing, enabling first the burial and then the exhumation of the high-pressure rocks. Note, however, that the exhumation path has not resulted in a generalized $L$ fabric, as it typically occurs under transtensional kinematics (e.g., Teyssier and Tikoff, 1999). For that reason, we use the double strikeslip and dip-slip shear model of Ellis and Watkinson (1988) in our estimates. According to this model and considering a shear zone dip of $45^{\circ}$ (Fig. 2, curve 3 in Ellis and Watkinson, 1988), the subhorizontal stretching lineation that characterizes the BCSZ would indicate a convergence/divergence angle of $15-35^{\circ}$. We take $25^{\circ}$ for our calculations in Fig. 3a; if the high-pressure rocks of the BCSZ reached depths of $\approx 55 \mathrm{~km}(1.6-1.7 \mathrm{GPa})$, then a left-lateral displacement of around $115 \mathrm{~km}$ is inferred during the exhumation of these rocks. If a similar calculation is considered for the previous burial path, 
(a) Devonian

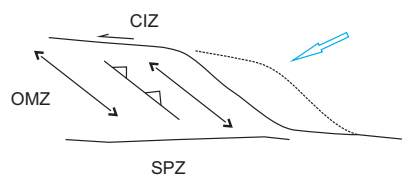

(b) Early-Middle Mississippian

(Transtensional stage)

(c) Late Mississippian
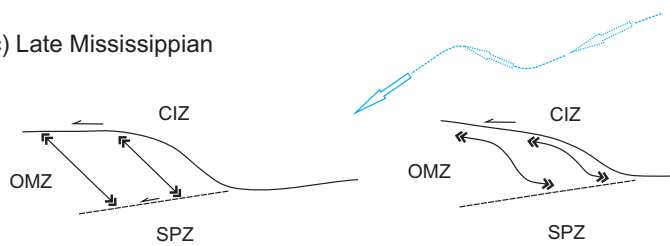

$\mathrm{OMZ}$

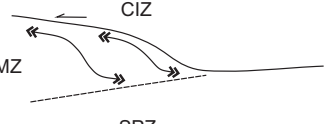

SPZ

(d)Pennsylvanian

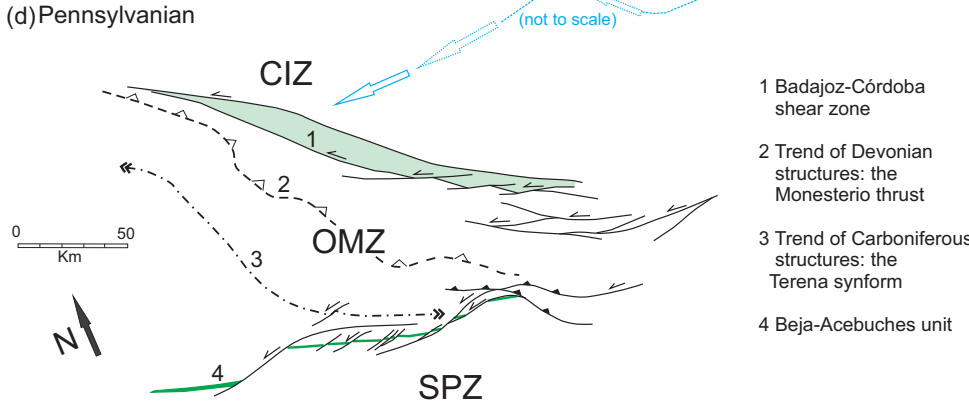

Figure 4. (a-d) Schematic evolutionary model of the deformations inside de OMZ from the Devonian to the Pennsylvanian period. See text for further explanations.

the whole subduction/exhumation path would amount to $\approx 230 \mathrm{~km}$ of left-lateral displacement.

From the above estimations, a great discrepancy exists between the results of the two models considered: $80-100 \mathrm{~km}$ and $230 \mathrm{~km}$, respectively. Actually, most or all of the shearing recorded in the BCSZ may correspond to the Carboniferous exhumation path (see above for the reported cooling metamorphic ages), thus explaining most of the difference. Anyway, because these calculations provide only a rough estimate, we will take an intermediate rather conservative value of $\approx 150 \mathrm{~km}$ for the whole ductile left-lateral displacement concentrated at the CIZ-OMZ boundary.

\section{Deformation inside the $\mathrm{OMZ}$}

The OMZ records Devonian and Carboniferous compressional events (folds and thrusts), separated by the EarlyMiddle Mississippian transtensional stage (Pérez-Cáceres et al., 2015). The Devonian deformation gave way to SWvergent recumbent folds and thrusts, while the Carboniferous one caused upright or slightly vergent folds and reverse faults (Fig. 1c). The two sets of folds have subparallel axes (Expósito et al., 2002); their axial traces trend oblique to the OMZ boundaries, depicting a $Z$ shape, in accordance with a left-lateral component of transpression increasing towards the borders (Fig. 1c). The Devonian tectonic fabric is $S$ or $S$ - $L$ type, the stretching/mineral lineation is at high an- gles to the fold axes and the strain ellipsoids are generally oblate with very variable strain intensity $(2.5 \leq X / Z \leq 9)$ and no significant areal change on the $X / Z$ section (Expósito, 2000). Regarding the Carboniferous tectonic fabric, it is generally planar with a steeply plunging $X$ axis.

A continuous transpressional evolution has been suggested for the OMZ (Silva and Pereira, 2004) but there is no theoretical transpressional model that fits the complex and heterogeneous evolution of the OMZ. As a basic kinematic analysis, we propose the evolution schematically displayed in Fig. 4, which accounts for the following geometrical features: (i) the axial traces of the Carboniferous folds (as depicted by the Terena syncline) (Fig. 1c) are smoothly curved, trending NNW-SSE at the central OMZ and WNW-ESE towards its borders; (ii) the Devonian folds and thrusts trend subparallel to the Carboniferous ones, though the Devonian axial surfaces are folded (type 3 interference fold pattern; Ramsay and Huber, 1987) (Fig. 1c) and (iii) the northern and southern OMZ boundaries are not parallel (Fig. 1c), the obliquity having been enhanced during the Carboniferous transpression (Fig. 4c, d).

The Carboniferous shortening can be divided into the two stages shown in Figs. 4c and 5: (i) first, a set of folds formed due to SW-NE compression, its original orientation being preserved in the central OMZ (Fig. 5a); (ii) then, these folds rotated heterogeneously to reach a $Z$ shape in map view, 
(a)

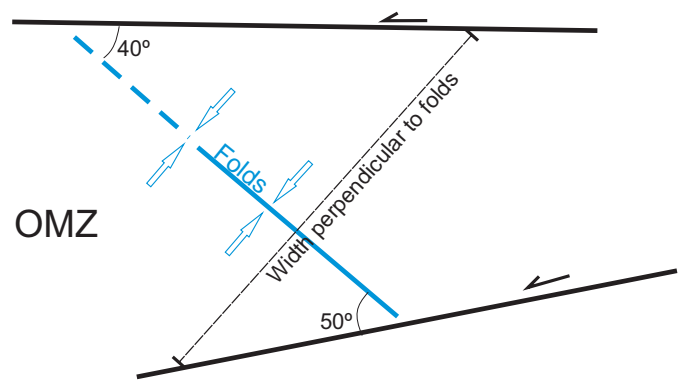

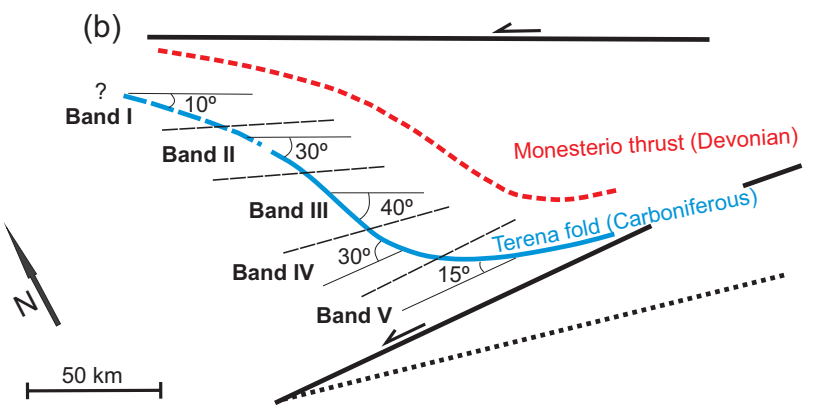

Figure 5. Stages of Carboniferous shortening inside the OMZ. (a) NE-SW compression gave way to a set of upright folds. (b) Folds rotation by heterogeneous left-lateral shearing. The five different bands considered to analyze the deformation are depicted.

congruent with left-lateral transpression (Fig. 5b). These two stages are described below.

(i) The width of the central OMZ as measured perpendicular to the original trend of the Carboniferous folds is $\approx 150 \mathrm{~km}$ (Fig. 5a). As regards to the finite strain, the available data are insufficient for an accurate evaluation of shortening. Let us take a conservative shortening of $\approx 35 \%$, just enough to generate the axial-plane Carboniferous foliation observed in these rocks. Accordingly, a shortening of $\approx 80 \mathrm{~km}$ would have taken place perpendicular to the folds, which means, in turn, that the width of the OMZ just before Carboniferous folding would have been $\approx 230 \mathrm{~km}(150+80)$. Given the oblique orientation of the shortening direction with respect to the CIZ-OMZ boundary $\left(50^{\circ}\right.$; Figs. $4 \mathrm{c}$ and 5$)$, the corresponding left-lateral component parallel to the CIZ-OMZ boundary is $\approx 55 \mathrm{~km}$.

(ii) In the second stage, the trend of the Carboniferous folds rotated heterogeneously. This rotation can be modeled according to the transpressional equation of Fossen and Tikoff (1993), but the simpler equation $\cot \Phi^{\prime}=\alpha \cot$ $\Phi+\gamma$ of Sanderson and Marchini (1984) will be used here in view of our main interest in evaluating finite lateral displacements $\left(\Phi^{\prime}\right.$ and $\Phi$ are the final and original angles of the rotated line, $\alpha$ is the vertical stretch and $\gamma$ is the shear strain parallel to the boundary). To analyze this deformation, the OMZ has been divided into five bands, each one characterized by a particular reorientation angle (Fig. 5b). As rotation is concentrated at the two boundaries of the OMZ (Fig. 4c) deformation must involve a dominant shear component; thus, we have tentatively assumed a modest value $\alpha^{-1}=0.7(\alpha=1.43)$ obtaining the following results.

- Band I $\left(\Phi^{\prime}=10^{\circ}, \Phi=40^{\circ}\right.$, width $\left.=40 \mathrm{~km}\right)$ would have undergone a shear strain of $\gamma=4$, which results in $160 \mathrm{~km}$ of left-lateral displacement.

- Band II $\left(\Phi^{\prime}=30^{\circ}, \Phi=40^{\circ}\right.$, width $\left.=13 \mathrm{~km}\right)$ would have undergone approximately zero shear strain (only frontal shortening).
- Band III is considered to have preserved the original orientation.

- Band IV $\left(\Phi^{\prime}=30^{\circ}, \Phi=50^{\circ}, \quad\right.$ width $\left.=17 \mathrm{~km}\right)$ would have undergone a shear strain of $\gamma=0.53$, causing $9 \mathrm{~km}$ of left-lateral displacement.

- Finally, band V $\left(\Phi^{\prime}=15^{\circ}, \quad \Phi=50^{\circ}\right.$, width $=23 \mathrm{~km})$ is characterized by $\gamma=2.53$ and a left-lateral displacement of $58 \mathrm{~km}$.

Overall, these calculations based on the sinistral rotation of the Carboniferous folds amount to $\approx 225 \mathrm{~km}$. Added to the $55 \mathrm{~km}$ of left-lateral displacement calculated above, the total left-lateral Carboniferous displacement would amount to $\approx 280 \mathrm{~km}$. Notice that considering a simple shear model to explain these rotations, instead of a transpressional one, would result in a greater left-lateral component. On the contrary, a lower left-lateral component would result from considering rotations as due to orthogonal shortening, but this interpretation seems to be at odds with the observed increasing rotation towards the boundaries of the OMZ.

Devonian deformation in the OMZ can be analyzed taking into account the subparallelism of Devonian and Carboniferous fold axes (Fig. 4d). Like for the Carboniferous structures, we assume that the original trend of the Devonian structures is observed at the central part of the OMZ ( $40^{\circ}$ with respect to the northern border of the OMZ). Devonian shortening would be perpendicular to this trend and, as said above, the width of the OMZ before Carboniferous deformation would be $230 \mathrm{~km}$. On the other hand, an approximate mean strain ratio $X / Z \approx 5$ can be proposed from the available range of strain measures $(2.5 \leq X / Z \leq 9$; Expósito, 2000), which results in $Z=0.44$ if the $X Z$ area remained unchanged and a Devonian shortening of $\approx 290 \mathrm{~km}$. Given the oblique orientation of the shortening direction with respect to the CIZ-OMZ boundary, the resulting leftlateral Devonian displacement would be $\approx 185 \mathrm{~km}$, and the total left-lateral Devonian plus Carboniferous displacement would amount to $\approx 465 \mathrm{~km}$. Note that a lower (conservative) mean strain $X / Z=4$ yields substantially similar results: $230 \mathrm{~km}$ of Devonian shortening, of which $145 \mathrm{~km}$ is 
of Devonian left-lateral displacement, and then $\approx 425 \mathrm{~km}$ of total Devonian-Carboniferous left-lateral displacement. Finally, we have tested these results following a different approach, the shortening obtained from stratigraphic markers on the OMZ geological cross section (Simancas et al., 2003). On this ground, a transversal shortening of $\approx 57 \%$ is estimated, which entails (for a $150 \mathrm{~km}$-wide OMZ at present) a total shortening of $\approx 200 \mathrm{~km}$ and a left-lateral component of $\approx 130 \mathrm{~km}$. Added to the left-lateral displacement inferred from the rotation of Carboniferous folds $(\approx 225 \mathrm{~km}$; see above), a total figure of $\approx 355 \mathrm{~km}$ is obtained; i.e., lower than the previous numbers of 465 and $425 \mathrm{~km}$. Thus, despite the fact that our arguments are rather crude, a figure of $\approx 400 \mathrm{~km}$ can be a valuable approximation to the left-lateral displacement due to the Devonian and Carboniferous deformation inside the OMZ.

\section{Subduction/exhumation at the southern OMZ continental margin}

In the Middle-Late Devonian period, the southern continental margin of the OMZ subducted under the SPZ, as witnessed by exhumed high-pressure metasedimentary rocks of the OMZ cover included in the allochthonous Cubito-Moura unit (Fig. 2a) (Fonseca et al., 1999; Araújo et al., 2005; Booth-Rea et al., 2006). The kinematics of this event can be gauged by the early stretching lineation developed during exhumation, which once restored later folds, trends $\approx \mathrm{N} 70^{\circ} \mathrm{E}$, and shows top-to-the-ENE sense of shearing (Ponce et al., 2012 ). This orientation forms an angle of $\approx 30^{\circ}$ with the $\approx \mathrm{N} 100^{\circ} \mathrm{E}$ trend of the OMZ-SPZ boundary (Fig. 1). Based on the model of thrust-and-wrench shearing parallel to a subduction zone, this orientation of the stretching lineation would correspond to a convergence angle of $45-55^{\circ}$, depending on the dip of the subduction zone (curve 3 in Figs. 1 and 2 by Ellis and Watkinson, 1988). By contrast, the model of simple-inclined transpression (orthogonal shortening and strike-slip shearing with inclined walls) (Jones et al., 2004) suggests a more oblique convergence at an angle $\leq 20^{\circ}$. Since it is unclear which one of these two models fits better the SW Iberia tectonic scenario, we will take an intermediate convergence angle of $35^{\circ}$ for the next tentative calculation.

A rough estimate of the left-lateral displacement between the SPZ and the OMZ during this stage can be proposed based on (i) a simple subduction-exhumation channel with opposite senses of burial and exhumation (Fig. 3b), (ii) a convergence angle of $35^{\circ}$, (iii) an intermediate dip of $45^{\circ}$ for the subduction plane and (iv) a maximum depth of $\approx 50 \mathrm{~km}$ for the high-pressure rocks, corresponding to the maximum recorded pressure of $1.4 \mathrm{GPa}$ in the Cubito-Moura unit (Fonseca et al., 1999; Ponce et al., 2012; Rubio Pascual et al., 2013). According to these assumptions, a simple calculation yields $71 \mathrm{~km}$ of lateral displacement during burial and the same amount during exhumation, i.e., altogether $\approx 140 \mathrm{~km}$ of left-lateral displacement of the OMZ with respect to the SPZ during this Devonian event. The same line of reasoning results in 100 and $270 \mathrm{~km}$ of left-lateral displacement for extreme convergence angles of 45 and $20^{\circ}$, respectively.

\section{Emplacement of the Beja-Acebuches mafic/ultramafic belt}

Along the OMZ-SPZ boundary, an intrusion of mafic and ultramafic rocks (the BA unit; Fig. 1c; Quesada et al., 1994) was emplaced during the transtensional stage that dominated all of SW Iberia during the earliest Carboniferous (Azor et al., 2008) (Fig. 2b). There are no kinematic indicators but an undefined left-lateral transtension is suggested in order to maintain the same lateral displacements as in the previous (see above) and subsequent (see below) convergent stages (Fig. 4). The lateral displacement due to this event has not been taken into account in our kinematic assessment.

\section{Obductive thrust of the Beja-Acebuches unit}

The convergence between the OMZ and the SPZ was resumed very soon after the formation of the BA unit. The renewed convergence resulted in hot obductive thrust of the BA unit onto the OMZ border (Fig. 2c) (Fonseca and Ribeiro, 1993; Pérez-Cáceres et al., 2015). As in the previous stage, the lack of kinematic indicators prevents from knowing the specific thrusting vector, presumably oblique to the OMZSPZ boundary.

\section{Ductile shearing and folding at the OMZ-SPZ boundary}

After the obductive thrust referred above, the convergent evolution became characterized by the interplay between largescale folding and left-lateral shearing (Fig. 6) (Pérez-Cáceres et al., 2015).

The OMZ-SPZ boundary was affected by an E-Wtrending south-vergent fold (Quintos fold) (Figs. 2d and 6). Coeval to the Quintos fold, ductile shearing came about concentrated in the BA unit, which evolved from high- to low-temperature (the so-called Southern Iberian shear zone; Crespo-Blanc and Orozco, 1988; Díaz-Azpiroz and Fernández, 2005; Fernández et al., 2013). The age of these deformations is constrained in the range 340-335 Ma (Late Visean), according to the available geochronological data (Dallmeyer et al., 1993; Castro et al., 1999).

The high-temperature rocks of the Southern Iberian shear zone (granulite and high-temperature amphibolite facies) are middle-grained and display foliation and compositional layering and, sometimes, mineral lineation. The low-temperature rocks (amphibolite and greenschist facies) are fine-grained and show a well-developed $S$ - $L$ mylonitic 
(a) Northwards obduction and high-temperature shearing

(b) High-temperature shearing and south-verging folding

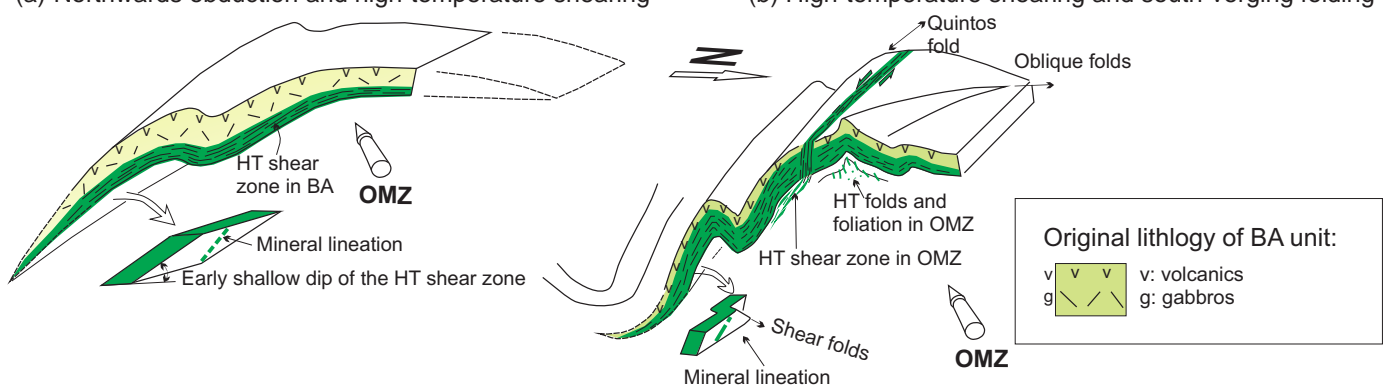

(c) Low-temperature shearing and southwards propagation of the deformation

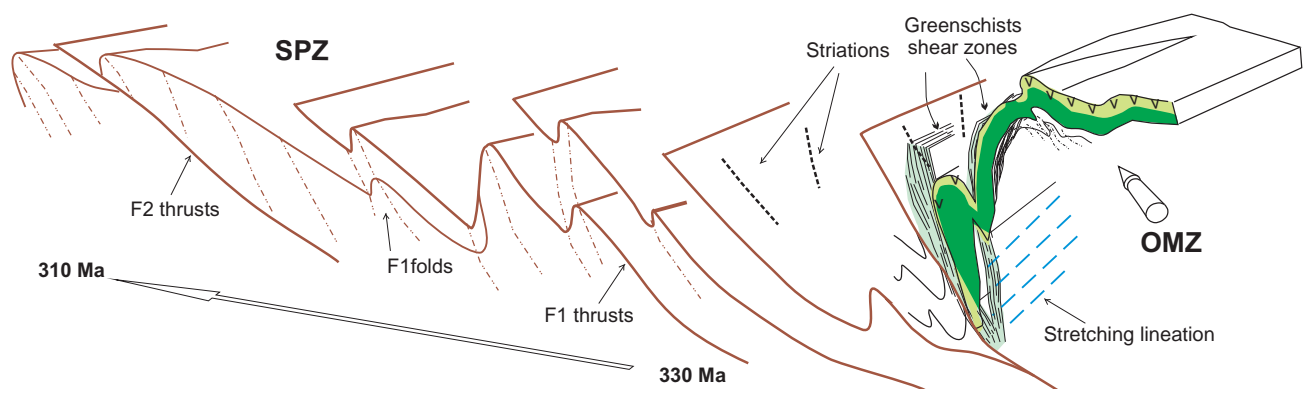

Figure 6. (a-c) Evolutionary model of the BA unit during the Carboniferous transpression, from northward obduction to southward propagation of the deformation. Modified from Pérez-Cáceres et al. (2015).

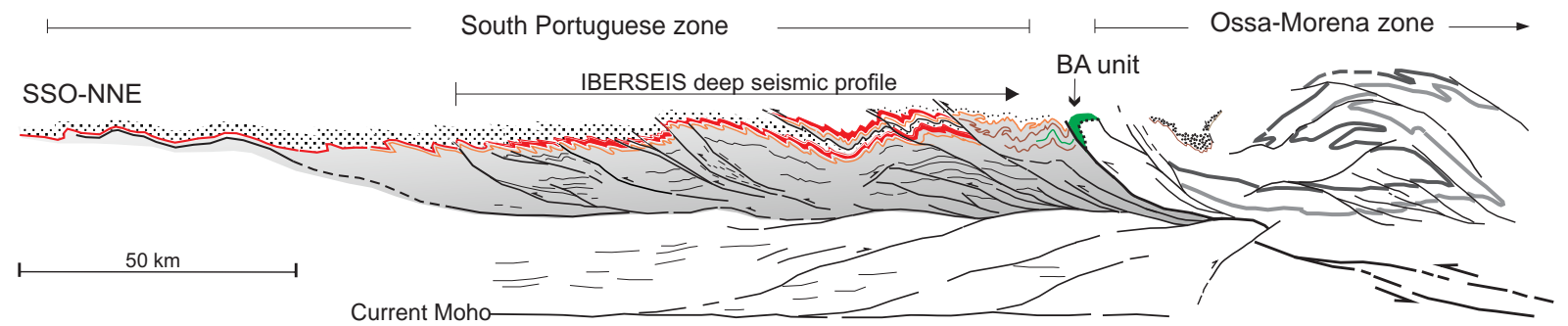

Figure 7. Schematic structural cross section of the southern OMZ and SPZ (modified from Simancas et al., 2003). See Fig. 1c for location.

fabric with abundant microstructures indicating left-lateral shear sense (Crespo-Blanc, 1991; Díaz-Azpiroz and Fernández, 2005; Fernández et al., 2013). The pitch of the high-temperature mineral lineation is medium to high to the E-NE, while the stretching/mineral lineation in the lowtemperature rocks has medium to low pitch angles to the ESE.

The evolution displayed in Fig. 6 (Pérez-Cáceres et al., 2015) indicates that the high-temperature fabric would have been developed when the shear zone had low dip, while the low-temperature one would have been formed in a steeper shear zone, as the Quintos fold was getting tighter. Accordingly, the transpression model of simple-inclined walls (Jones et al., 2004) provides a possible explanation for the observed pitch variation; at an angle of convergence $\beta \approx 10^{\circ}$ and a shortening $S<0.2$ (simple-shear-dominated transpressional zones), the model predicts pitch angles of 50$60^{\circ}$ when the dip of the shear zone is $20^{\circ} \leq \delta \leq 30^{\circ}$, and pitch angles of $10-35^{\circ}$ when the dip of the shear zone is $50^{\circ} \leq \delta \leq 80^{\circ}$.

Regardless of the transpression model considered, the leftlateral displacement due to the Southern Iberian shear zone cannot be accurately calculated. Assuming that the mafic layering corresponds to dykes intruded in gabbro (Quesada et al., 1994) and considering that layering and foliation are almost parallel, a $\gamma \geq 4$ can be proposed (simple shear). Considering that the maximum thickness of the BA unit is $\approx 2000 \mathrm{~m}$ across its ghost stratigraphy (metabasaltsgabbros-ultramafites), a plausible shear strain $\gamma=5$ would correspond to a left-lateral displacement of only $10 \mathrm{~km}$, which is a rather modest figure. Reasonably higher or lower values of $\gamma$ would not result in greater regionally significant lateral displacements. 


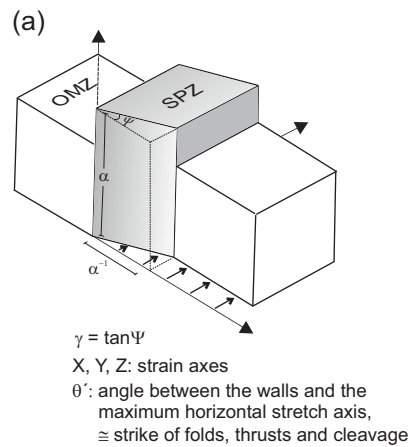

(c)

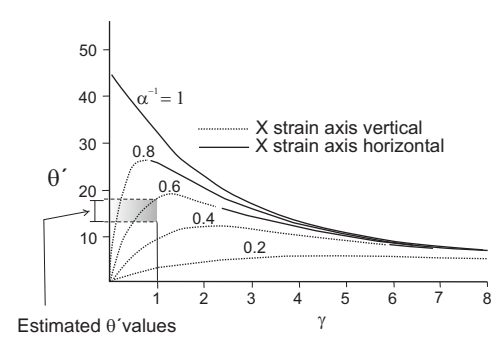

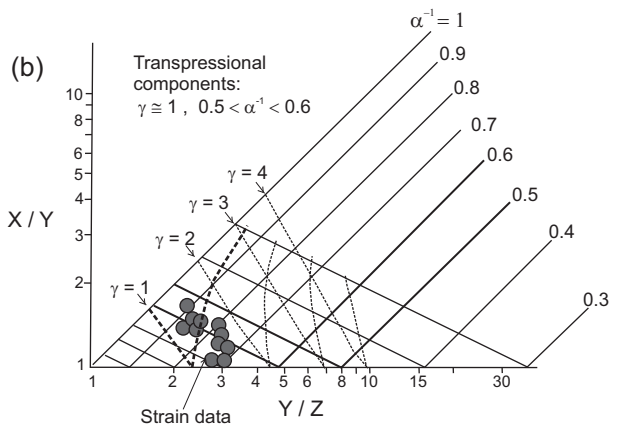

(d)

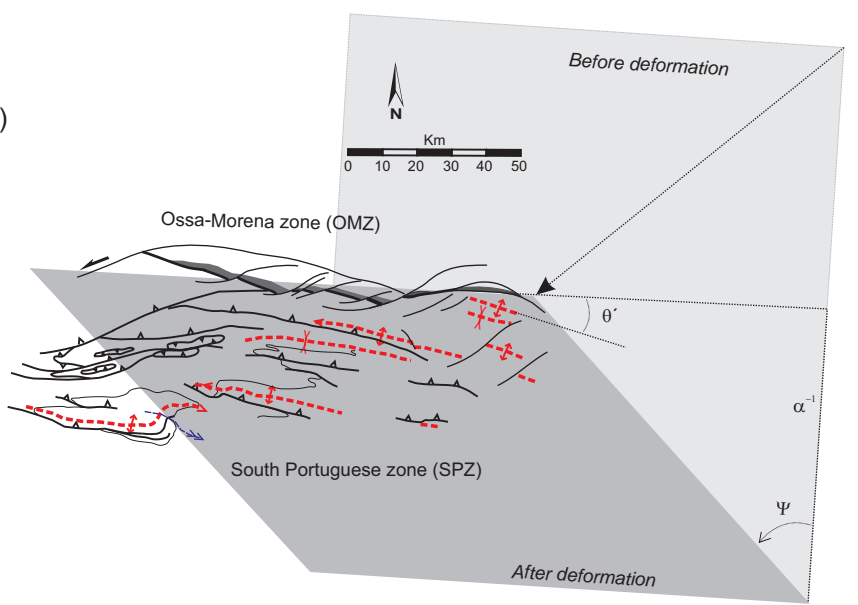

Figure 8. (a) Transpressional model of Sanderson and Marchini (1984). (b) Strain data from the SPZ suggest the values of shortening ( $\alpha$ ) and shearing $(\gamma)$ according to this model. (c) Angle between the boundary of the transpressional block and the maximum horizontal stretch axis, according to the estimated $\alpha$ and $\gamma$ values. (d) Sketch of the eastern SPZ showing the transpressional deformation.

\section{Deformation inside the SPZ}

The SPZ is a fold-and-thrust belt made up of low-grade slates, metasandstones and metavolcanic rocks of Devonian to Carboniferous age (Fig. 7). The fold-and-thrust system is rooted in a detachment level located at the middle crust (IBERSEIS seismic profile; Simancas et al., 2003). Deformation propagated southwards from the late Visean to Moscovian period (Oliveira, 1990). At the western part of the SPZ, its structural trend deviates from the common WNW-ESE trend, due to the influence of the N-S-oriented Porto-Tomar dextral fault (Ribeiro et al., 1980) (Fig. 1b). For this reason, we do not consider this western part in the following analysis.

Relevant features of the SPZ deformation include the following (Simancas, 1986). (i) The foliation trends $\mathrm{N} 105^{\circ} \mathrm{E}$ (Fig. 8d) and dips $50^{\circ}$ to the north on average. (ii) The tectonic fabric is planar ( $S$-tectonites), locally exhibiting a faint stretching lineation noticeable in pyroclastic rocks; $S-L$ tectonites are observed only at localized thrust bands. (iii) When visible, the stretching lineation shows high-pitch angles of $65-90^{\circ}$. (iv) Finite strain ellipsoids are oblate with the $X$ axis always upright. (v) Folds axes display a remarkably variable plunging, with smooth curved hinges observed at outcrop. (vi) Fold traces are slightly oblique clockwise with respect to the OMZ-SPZ boundary, thus suggesting left-lateral transpression.

The deformation of the SPZ is partitioned into strain, buckle folds and thrusts at local scale, but considered as a whole it can be approximated to a bulk homogeneous deformation that can be analyzed in the light of a suitable transpressional model. In this respect, the northern wall of the SPZ transpressional zone is the currently steep Southern Iberian shear zone, the southern wall is loosely defined at the southernmost SPZ and the base of the transpressional zone is the mid-crustal detachment imaged in the IBERSEIS seismic section (Fig. 7). Furthermore, significant lateral escape of the deformed rock volume (Jones et al., 1997) can be rejected, since folds show smooth curved hinges. Finally, as the $X$ finite strain axis roughly but consistently coincides with the dip direction, then the bulk strain symmetry may be considered approximately monoclinic (Lin et al., 1998, 1999). Thus, the boundary conditions of the SPZ fit reasonably well with those in the models of Sanderson and Marchini (1984), who factorized bulk strain into finite pure shearing followed by simple shearing, and Fossen and Tikoff (1993), who modeled simultaneous superposition of the strain components. The latter model is in general a more realistic way of model- 
(a)

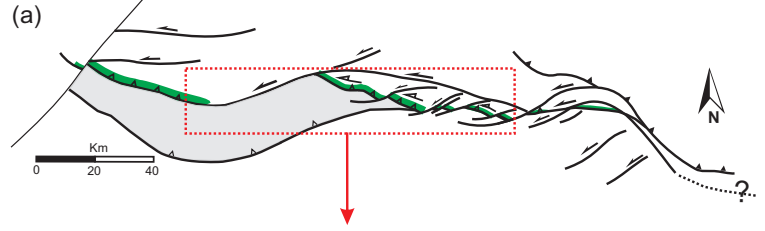

(b)

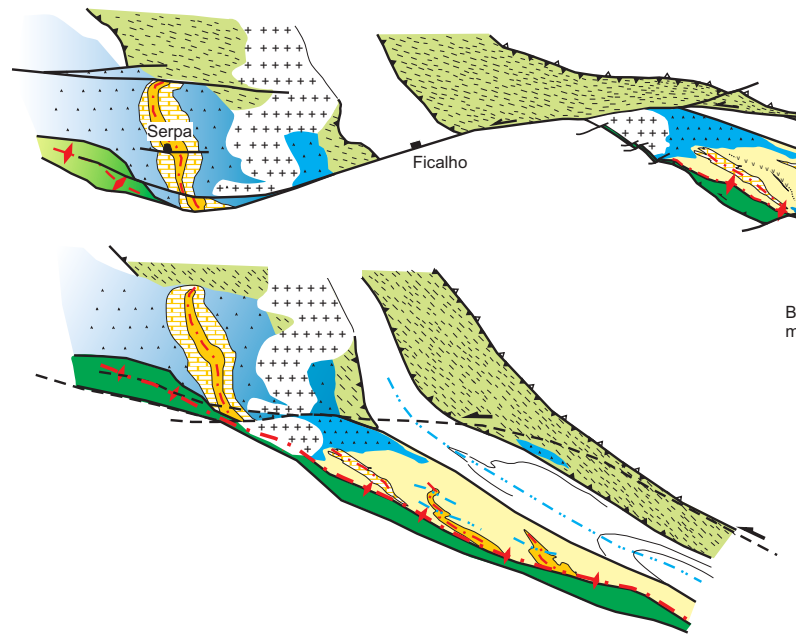

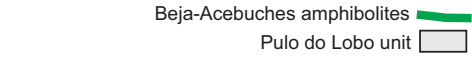

Left-lateral ductile shear zone (upper Visean) Thrusts (pper Visean-Bashkirian)

Strike-slip brittle faults and associated thrusts (pper Pennsylvanian)

Figure 9. (a) Schematic map of the main late Variscan faults affecting the OMZ-SPZ boundary. Compare with Fig. 1c for location. (b) Map of the central part of the OMZ-SPZ boundary, showing the main Ficalho fault and the set of shorter faults affecting the Aracena-Cortegana sector. (c) Reconstruction of this central part before the brittle faulting.

(a)

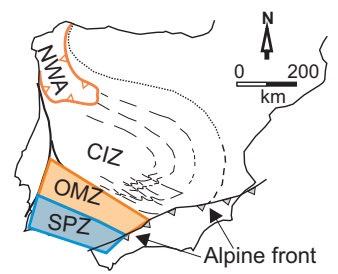

(c)

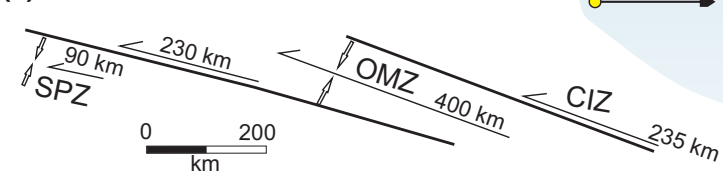

(b)

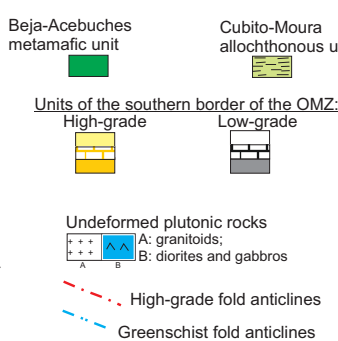

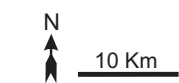

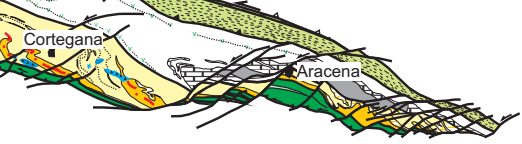

$$
\text { . }
$$


the bulk shear strain thus obtained gives us the approximate value of the bulk left-lateral displacement (Fig. 8a).

Strain data from the SPZ have been projected in the finite strain grid of Sanderson and Marchini (1984) (Fig. 8b), suggesting a bulk transversal shortening of $\approx 40 \%\left(\alpha^{-1} \approx\right.$ 0.6 ) and a shear strain of $\gamma \approx 1$ (bulk angular shear strain $\psi=45^{\circ}$ ). For the $\alpha^{-1}$ and $\gamma$ values deduced above, the transpressional model used predicts that the long axis of the horizontal strain ellipse (map view) would be oriented at $\theta^{\prime}=18^{\circ}$ with a vertical $X$ strain axis, in reasonable agreement with the data (Fig. 8c). Thus, the bulk strain of the SPZ can be factorized into a transversal shortening of $\approx 40 \%$ followed by a strike-slip shearing of $\gamma \approx 1\left(\psi=45^{\circ}\right)$. Taking $\mathrm{a} \approx 90 \mathrm{~km}$ width for the SPZ (excluding the less-deformed SW sector), that shear strain yields a left-lateral relative displacement of the $\mathrm{OMZ}$ with respect to the $\mathrm{SPZ}$ of $\approx 90 \mathrm{~km}$. This finite strain factorization has been geometrically depicted in Fig. 8d. Modeling our data of the SPZ in terms of simultaneous superposition with constant simple shear/pure shear ratio (Fossen and Tikoff, 1993) does not yield significantly different results, but just a slightly higher bulk angular shear strain $\left(\psi \approx 50^{\circ}\right)$.

\section{Brittle faulting}

Left-lateral strike-slip faults characterize the late Variscan evolution of SW Iberia. These brittle structures concentrated at the northern and southern boundaries of the OMZ (Fig. 1c). The system of strike-slip faults at the CIZ-OMZ boundary was analyzed by Jackson and Sanderson (1992) based on a power-law distribution of fault displacements from outcrop to map scale. As a result, they evaluated $87 \mathrm{~km}$ of along-strike brittle displacement.

A well-organized left-lateral strike-slip fault system started to develop at the OMZ-SPZ boundary in the Moscovian period, coeval with folding and thrusting deformation at the southwesternmost SPZ, as attested by synorogenic flysch deposits (Fig. 9; Oliveira, 1990). Two faulting stages can be differentiated (Simancas, 1983). First, two smoothly curved E-W-oriented major faults divided the southernmost OMZ into three lens-shaped blocks, their summed slip accounting for $75 \%(55-60 \mathrm{~km})$ of the total slip of the left-lateral brittle faulting. These two faults concentrated the strike-slip component of the transpression, while simultaneous orthogonal shortening occurred at the southwesternmost SPZ (Carrapateira thrust; Ribeiro and Silva, 1983). The second faulting stage is characterized by a set of en échelon NE-SW shorter faults summing $\approx 20 \mathrm{~km}$ of slip. Thus, the total strike-slip of all the faults amounts to $80 \mathrm{~km}$. This brittle shearing just preceded the attachment of the SPZ to the OMZ.

\section{Discussion and conclusions}

From the Middle-Late Devonian to Pennsylvanian period, the collisional evolution of SW Iberia is characterized by oblique left-lateral convergence between three continental terranes: the CIZ (representing the northern margin of Gondwana), the OMZ (a fragment of the Gondwana margin) and the SPZ (the southern margin of Avalonia). Oblique convergence resulted in strain partitioning with the boundaries between the terranes accumulating preferentially the left-lateral component, and the interior of them exhibiting both orthogonal and lateral components of deformation.

\subsection{The big numbers of SW Iberia Variscan transpression}

This paper is the first attempt to evaluate regional left-lateral displacement in SW Iberia due to the oblique collision of continental terranes during the Variscan orogeny. We are aware of the approximate nature of our calculations, but we contend that the big numbers thus obtained have strong regional significance. As a synthesis, the quantification of the Variscan deformations in SW Iberia described above yields the following results, from north to south (Fig. 10).

(i) CIZ-OMZ boundary

- The ductile shearing that occurred in the BCSZ during the Upper Devonian-Mississippian period has been quantified to $\approx 150 \mathrm{~km}$ of left-lateral displacement, roughly parallel to the CIZ-OMZ boundary.

- The late Variscan strike-slip fault system that developed at the CIZ-OMZ boundary produced $\approx 85 \mathrm{~km}$ of left-lateral displacement parallel to this boundary.

(ii) Inner $\mathrm{OMZ}$

- The Devonian SW-vergent folds and thrusts of the OMZ terrane might have accumulated $\approx 290 \mathrm{~km}$ of NE-SW-directed shortening with a left-lateral component parallel to the CIZ-OMZ boundary of $\approx 185 \mathrm{~km}$.

- The Carboniferous upright folds of the OMZ terrane accumulated $\approx 80 \mathrm{~km}$ of $\mathrm{NE}-\mathrm{SW}$ shortening with a left-lateral component parallel to the CIZOMZ boundary of $\approx 55 \mathrm{~km}$.

- The rotation of the OMZ Carboniferous folds to a $\mathrm{Z}$ shape has been modeled as being due to left-lateral shearing plus with limited perpendicular shortening, thus resulting in $\approx 225 \mathrm{~km}$ of displacement subparallel to the $\mathrm{OMZ}$ boundaries.

The sum of left-lateral displacements due to Devonian and Carboniferous deformation inside the $\mathrm{OMZ}$ amounts to $\approx 465 \mathrm{~km}$, according to the above data. 
However, plausible calculations yield lower values of $\approx 425$ and $\approx 355 \mathrm{~km}$. Thus, we suggest an alternative value of $\approx 400 \mathrm{~km}$.

(iii) OMZ-SPZ boundary

- The Devonian subduction/exhumation on the southern margin of the OMZ, as represented by the allochthonous Cubito-Moura unit, took place in a left-lateral setting that amounts to $\approx 140 \mathrm{~km}$ of displacement parallel to the OMZ-SPZ boundary.

- The displacement figures of the transtensional Early-Middle Mississippian stage that gave way to the BA oceanic-like realm cannot be evaluated, though this event most probably occurred in a continued left-lateral tectonic setting. An alike scenario can be envisaged for the subsequent obduction of the BA unit, though with renewed transpression.

- The Southern Iberian shear zone that deformed the BA unit reveals $\approx 10 \mathrm{~km}$ of left-lateral displacement parallel to the OMZ-SPZ boundary.

- The late Variscan strike-slip fault system that developed at the OMZ-SPZ boundary produced $\approx 80 \mathrm{~km}$ of left-lateral displacement parallel to the boundary.

(iv) Inner SPZ

- The transpressional fold-and-thrust belt of the SPZ terrane produced $\approx 90 \mathrm{~km}$ of left-lateral displacement parallel to the OMZ-SPZ boundary with $\approx 60 \mathrm{~km}$ of orthogonal shortening.

The above numbers are estimations that must be considered as valuable but approximate to the real ones, given the variety of uncertainties in the kinematic analysis performed.

\subsection{Relative displacements of SW Iberian terranes}

Considered altogether, the total collisional convergence recorded in SW Iberia is E-W-oriented and surpasses $1000 \mathrm{~km}$. The left-lateral component parallel to terrane boundaries is estimated to be $\approx 1000 \mathrm{~km}$, half of which accumulated as strike-slip shearing at the two suture boundaries (Fig. 10c). This main conclusion brings up an image of the paleoposition of SW Iberian continental terranes just before the Devonian-Carboniferous Variscan collision. The remarkable left-lateral oblique kinematics during the Variscan plate convergence in SW Iberia, as opposed to the dominant right-lateral kinematics of the Variscan/Alleghanian orogen (Fig. 1a), is also inferred from our kinematic analysis. We interpret that the reason for the singular kinematics of SW Iberia is the existence of an Avalonian salient, currently represented by the SPZ (Figs. 1a and 10b).

Finally, it is important to emphasize that in-between these regions with opposite kinematics (left-lateral oblique convergence in SW Iberia and right-lateral oblique convergence in central Europe), an intermediate one with rather orthogonal convergence must have existed (Fig. 1a), which would had to accommodate the $>1000 \mathrm{~km}$ of collisional convergence evaluated above. In NW Iberia, a major unrooted allochthonous pile with continental and oceanic-like units has been described for the para-autochthonous CIZ (Martínez Catalán et al., 1997). Thus, NW Iberia may represent this intermediate region with orthogonal collision.

Acknowledgements. Financial support was provided by grants CGL2011-24101 and CGL2015-71692-P (Spanish Ministry of Science and Innovation), RNM-148 (Andalusian government) and BES-2012-055754 (Doctoral scholarship to I. Pérez-Cáceres from the Spanish Ministry of Science and Innovation). We thank Carlos Fernández for his critical reading of an early draft of this paper and two anonymous referees for their detailed revision. We also appreciate the editorial labor carried out by Charlotte Krawczyk.

Edited by: C. Krawczyk

\section{References}

Abalos, B., Gil Ibarguchi, J. I., and Eguiluz, L.: Cadomian subduction/collision and Variscan transpression in the Badajoz-Córdoba shear belt, southwest Spain, Tectonophysics, 199, 51-72, 1991.

Araújo, A., Fonseca, P., Munhá, J., Moita, P., Pedro, J., and Ribeiro, A.: The Moura Phyllonitic Complex: An accretionary complex related with obduction in the southern Iberia Variscan suture, Geodin. Acta, 18, 375-388, 2005.

Azor, A., González Lodeiro, F., and Simancas, J. F.: Tectonic evolution of the boundary between the Central Iberian and OssaMorena zones (Variscan Belt, southwest Spain), Tectonics, 13, 45-61, 1994.

Azor, A., Rubatto, D., Simancas, J. F., González Lodeiro, F., Martínez Poyatos, D., Martín Parra, L. M., and Matas, J.: Rheic Ocean ophiolitic remnants in Southern Iberia questioned by SHRIMP U-Pb zircon ages on the Beja-Acebuches amphibolites, Tectonics, 27, TC5014, doi:10.1029/2009TC002527, 2008.

Bandrés, A., Eguíluz, L., Pin, C., Paquette, J. L., Ordóñez, B., Le Fèvre, B., Ortega, L. A., and Gil Ibarguchi, J. I.: The northern Ossa-Morena Cadomian batholith (Iberian Massif): magmatic arc origin and early evolution, Int. J. Earth Sci., 93, 860-885, 2004.

Bard, J. P.: Signification tectonique des métatholeites d'affinité abyssale de la ceinture de basse pression d'Aracena (Huelva, Espagne), Bulletin de la Société géologique de France, 19, 385393, 1977.

Booth-Rea, G., Simancas, J. F., Azor, A., Azañón, J. M., Gonzalez Lodeiro, F., and Fonseca, P.: HP-LT Variscan metamorphism in the Cubito-Moura schists (Ossa-Morena Zone, southern Iberia), C. R. Geosci., 338, 1260-1267, 2006.

Braid, J. A., Murphy, J. B., and Quesada, C.: Structural analysis of an accretionary prism in a continental collisional setting, the Late Paleozoic Pulo do Lobo Zone, Southern Iberia, Gondwana Res., 17, 422-439, 2010.

Burg, J. P., Iglesias, M., Laurent, P., Matte, P., and Ribeiro, A.: Variscan intracontinental deformation: the Coimbra-Córdoba 
Shear zone (SW Iberian Peninsula), Tectonophysics, 78, 161$177,1981$.

Castro, A., Fernández, C., De la Rosa J. D., Moreno Ventas, I., and Rogers, G.: Significance of MORB-derived amphibolites from the Aracena metamorphic belt, southwest Spain, J. Petrol., 37, 235-260, 1996.

Castro, A., Fernández, C., El-Hmidi, H., El-Biad, M., DíazAzpiroz, M., De la Rosa, J., and Stuart, F.: Age constraints to the relationships between magmatism, metamorphism and tectonism in the Aracena metamorphic belt, southern Spain, Int. J. Earth Sci., 88, 26-37, 1999.

Crespo-Blanc, A.: Evolución geotectónica del contacto entre la zona de Ossa-Morena y la zona Surportuguesa en las sierras de Aracena y Aroche (Macizo Ibérico Meridional): Un contacto mayor en la cadena Hercínica Europea, Ph. D. Thesis, Univ. de Granada, 327 pp., 1991.

Crespo-Blanc, A.: Structure and kinematics of a sinistral transpressive suture between the Ossa-Morena and the South Portuguese Zones, South Iberian Massif, J. Geol. Soc. London, 149, 401411, 1992.

Crespo-Blanc, A. and Orozco, M.: The southern Iberian shear zone: a major boundary in the Hercynian folded belt, Tectonophysics, 148, 221-227, 1988.

Czeck, D. M. and Hudleston, P. J.: Testing models for obliquely plunging lineations in transpression: a natural example and theoretical discussion, J. Struct. Geol., 25, 959-982, 2003.

Czeck, D. M. and Hudleston, P. J.: Physical experiment of vertical transpression with localized non vertical extrusion, J. Struct. Geol., 26, 573-581, 2004.

Dahn, D. R. L., Braid, J. A., Murphy, J. B., Quesada, C., Dupuis, N., and McFarlane, C. R. M.: Geochemistry of the Peramora Melange and Pulo do Lobo schist: geochemical investigation and tectonic interpretation of mafic melange in the Pangean suture zone, Southern Iberia, Int. J. Earth Sci., 103, 1415-1431, 2014.

Dallmeyer, R. D., Fonseca, P. E., Quesada, C., and Ribeiro, A.: ${ }^{40} \mathrm{Ar} /{ }^{39} \mathrm{Ar}$ Mineral age constraints for the Tectonothermal Evolution of a Variscan Suture in Southwest Iberia, Tectonophysics, 222, 177-194, 1993.

Dewey, J., Holdsworth, R. E., and Strachan, R. A.: Discussion on transpression and transtension zones, J. Geol. Soc. London, 156, 1048-1050, 1999.

Dias, R. and Ribeiro, A.: Constriction in a transpressive regime: an example in the Iberian branch of the Ibero-Armorican Arc, J. Struct. Geol., 16, 1545-1554, 1994.

Díaz-Azpiroz, M. and Fernández, C.: Kinematic analysis of the southern Iberian shear zone and tectonic evolution of the Acebuches metabasites (SW Variscan Iberian Massif), Tectonics, 24, TC3010, doi:10.1029/2004TC001682, 2005.

Dutton, B. J.: Finite strains in transpression zones with no boundary slip, J. Struct. Geol., 19, 1189-1200, 1997.

Eden, C. P.: Tectonostratigraphic analysis of the northern extent of the oceanic exotic terrane, Northwestern Huelva Province, Spain, Ph. D. Thesis, Univ. of Southampton, 214 pp., 1991.

Eden, C. P. and Andrews, J.: Middle to upper Devonian melanges in SW Spain and their relationship to the Meneage formation in south Cornwall, Proc. Ussher, 7, 217-222, 1990.

Ellis, M. A. and Watkinson, A. J: Reply on "Orogen-parallel extension and oblique tectonics: The relation between stretching lineations and relative plate motions, Geology, 16, 857-861, 1988.
Expósito, I.: Evolución estructural de la mitad septentrional de la Zona de Ossa-Morena y su relación con el límite Zona de Ossa Morena/Zona Centroibérica, Ph. D. Thesis, Univ. de Granada, 296 pp., 2000.

Expósito, I., Simancas, J. F., González Lodeiro, F., Azor, A., and Martínez Poyatos, D.: Estructura de la mitad septentrional de la zona de Ossa-Morena: Deformación en el bloque inferior de un cabalgamiento cortical de evolución compleja, Revista de la Sociedad Geológica de España, 15, 3-14, 2002.

Fernández, C. and Díaz-Azpiroz, M.: Triclinic transpression zones with inclined extrusion, J. Struct. Geol., 31, 1225-1269, 2009.

Fernández, C., Czeck, D. M., and Díaz-Azpiroz, M.: Testing the model of oblique transpression with oblique extrusion in two natural cases: Steps and consequences, J. Struct. Geol., 54, 85-102, 2013.

Fonseca, P. and Ribeiro, A.: Tectonics of the Beja-Acebuches Ophiolite - a Major Suture in the Iberian Variscan Foldbelt, Geol. Rundsch., 82, 440-447, 1993.

Fonseca, P., Munhá, J., Pedro, J., Rosas, F., Moita, P., Araújo, A., and Leal, N.: Variscan ophiolites and high-pressure metamorphism in southern Iberia, Ofioliti, 24, 259-268, 1999.

Fossen, H. and Tikoff, B.: The deformation matrix for simultaneous simple shearing, pure shearing and volume change, and its application to transpression-transtension tectonics, J. Struct. Geol., 15, 413-422, 1993.

Franke, W.: The mid-European segment of the Variscides: Tectonostratigraphic units, terrane boundaries and plate tectonic evolution, in: Orogenic Processes: Quantification and Modelling in the Variscan Belt, edited by: Franke, W., Haak, V., Oncken, O., and Tanner, D., Geological Society of London Special Publications, 179, 35-61, 2000.

Gómez-Pugnaire, M. T., Azor, A., Fernández-Soler, J. M., and López Sánchez-Vizcaíno, V.: The amphibolites from the OssaMorena/Central Iberian Variscan suture (southwestern Iberian Massif): Geochemistry and tectonic interpretation, Lithos, 68, 23-42, 2003.

Harland, W. B.: Tectonic transpression in caledonian Spitsbergen, Geol. Mag., 108, 27-41. 1971.

Holdsworth, R. E. and Strachan, R. A.: Interlinked system of ductile strike slip and thrusting formed by Caledonian sinistral transpression in northeastern Greenland, Geology, 19, 510-513, 1991.

Jackson, P. and Sanderson, D. J.: Scaling of fault displacements from the Badajoz-Cordoba shear zone, SW Spain, Tectonophysics, 210, 179-190, 1992.

Jiang, D.: Sustainable transpression: An examination of strain and kinematics in deforming zones with migrating boundaries, J. Struct. Geol., 29, 1984-2005, 2007.

Jiang, D. and Williams, P. F.: High-strain zones: a unified model, J. Struct. Geol., 20, 1105-1120, 1998.

Jones, R. R., Holdsworth, R. E., and Bailey, W.: Lateral extrusion in transpression zones; the importance of boundary conditions, J. Struct. Geol., 19, 1201-1217, 1997.

Jones, R. R., Holdsworth, R. E., Clegg, P., McCaffrey, K., and Tavarnelli, E.: Inclined transpression, J. Struct. Geol., 26, 15311548, 2004.

Lin, S., Jiang, D., and Williams, P. F.: Transpression (or transtension) zones of triclinic symmetry: natural example and theoretical modelling, in: Continental Transpression and Transtension Tectonics, edited by: Holdsworth, R. E., Strachan, R. A., and 
Dewey, J. F., Geological Society of London Special Publications, 135, 41-57, 1998.

Lin, S., Jiang, D., and Williams, P. F.: Discussion on transpression and transtension zones, J. Geol. Soc. London, 156, 1045-1048, 1999.

Linnemann, U., Gehmlich, M., Tichomirowa, M., Buschmann, B., Nasdala, L., Jonas,P., Lützner, H., and Bombach, K.: The Cadomian Orogen: Neoproterozoic to Early Cambrian crustal growth and orogenic zoning along the periphery of the West African Craton - Constraints from U-Pb zircon ages and $\mathrm{Hf}$ isotopes (Schwarzburg Antiform, Germany), Precambrian Res., 244, 263-278, 2014.

López Sánchez-Vizcaíno, V., Gómez Pugnaire, M. T., Azor, A., and Fernández Soler, J. M.: Phase diagram sections applied to amphibolites: a case study from the Ossa-Morena/Central Iberian Variscan suture (Southwestern Iberian Massif), Lithos, 68, 1-21, 2003.

Martínez Catalán, J. R., Arenas, R., Díaz García, F., and Abati, J.: Variscan accretionary complex of northwest Iberia: terrane correlation and succession of tectonothermal events, Geology, 25, 1103-1106, 1997.

Martínez Poyatos, D.: Estructura del borde meridional de la Zona Centroibérica y su relación con el contacto entre las Zonas Centroibérica y de Ossa-Morena, Ph. D. Thesis, Univ. de Granada, 295 pp., 1997.

Matte, P.: Accretionary history and crustal evolution of the Variscan belt in Western Europe, Tectonophysics, 196, 309-337, 1991.

Matte, P.: The Variscan collage and orogeny (480-290 Ma) and the tectonic definition of the Armorica microplate: a review, Terra Nova, 13, 122-128, 2001.

Munhá, J., Oliveira, J. T., Ribeiro, A., Oliveira, V., Quesada, C., and Kerrich, R.: Beja-Acebuches ophiolite, characterization and geodynamic significance, Boletim da sociedade Geologica de Portugal, Maleo, 2, 31, 1986.

Murphy, J. B. and Nance, R. D.: A supercontinent model for the contrasting character of Late Proterozoic orogenic belts, Geology, 9, 469-472, 1991.

Oliveira, J. T.: Part VI: South Portuguese Zone, stratigraphy and synsedimentary tectonism, in: Pre-Mesozoic Geology of Iberia, edited by: Dallmeyer, R. D. and Martínez García, E., Springer, 334-347, 1990.

Ordóñez Casado, B.: Geochronological Studies of the PreMesozoic Basement of the Iberian Massif: The Ossa-Morena Zone and the Allochthonous Complexes within the Central Iberian Zone, Ph. D. Thesis, ETH, Zürich, 235 pp., 1998.

Pereira, M. F., Apraiz, A., Chichorro, M., Silva, J. B., and Armstrong, R. A.: Exhumation of high pressure rocks in northern Gondwana during the Early Carboniferous (Coimbra-Cordoba shear zone, SW Iberian Massif): tectonothermal analysis and UTh-Pb SHRIMP in-situ zircon geochronology, Gond. Res., 17, 440-460, 2010.

Pérez-Cáceres, I., Martínez Poyatos, D., Simancas, J. F., and Azor, A.: The elusive nature of the Rheic Ocean suture in SW Iberia, Tectonics, 34, 2429-2450, 2015.

Pin, C., Liñán, E., Pascual, E., Donaire, T., and Valenzuela, A.: Late Neoproterozoic crustal growth in the European Variscides: $\mathrm{Nd}$ isotope and geochemical evidence from the Sierra de Córdoba Andesites (Ossa-Morena Zone, Southern Spain), Tectonophysics, 352, 133-151, 2002.
Ponce, C., Simancas, J. F., Azor, A., Martínez Poyatos, D., BoothRea, G., and Expósito, I.: Metamorphism and kinematics of the early deformation in the Variscan suture of SW Iberia, J. Metamor. Geol., 30, 625-638, 2012.

Quesada, C. and Dallmeyer, R. D.: Tectonothermal evolutionof the Badajoz-Córdoba shear zone (SW Iberia): characteristics and ${ }^{40} \mathrm{Ar} /{ }^{39} \mathrm{Ar}$ mineral age constraints, Tectonophysics, 231, 195213, 1994.

Quesada, C., Fonseca, P. E., Munhá, J., Oliveira J. T., and Ribeiro, A.: The Beja-Acebuches Ophiolite (Southern Iberia Variscan fold belt): geological characterization and significance, Boletín Geológico y Minero, 105, 3-49, 1994.

Ramsay, J. G. and Huber, M. I.: The Techniques of Modern Structural Geology, vol. 2, Folds and Fractures., Springer, 393 pp., 1987.

Ribeiro, A. and Silva, J. B.: Structure of the South Portuguese Zone, in: The Carboniferous of Portugal, edited by: Sousa, M. J. L. and Oliveira, J. T., Memória dos Serviços Geológicos de Portugal, 29, 83-89, 1983.

Ribeiro, A., Pereira, E., and Severo, L.: Análise da deformaçao da zona de cisalhament Porto-Tomar na transversal de Oliveira de Azeméis, Comunicações dos Serviços Geológicos de Portugal, 66, 3-9, 1980.

Robardet, M.: Alternative approach to the Variscan Belt in southwestern Europe: pre-orogenic paleobiogeographical constraints, in: Variscan-Appalachian Dynamics: The Building of the Late Paleozoic Basement, edited by: Martínez Catalán, J. R., Hatcher, R., Arenas, R., and Díaz García, F., Geological Society of America Special Paper, 364, 1-15, 2002.

Robin, P. Y. F. and Cruden, A. R.: Strain and vorticity patterns in ideally ductile transpressional zones, J. Struct. Geol., 16, 447466, 1994.

Rodríguez-Alonso, M. D., Peinado, M., López-Plaza, M., Franco, P., Carnicero, A., and Gonzalo, J. C.: Neoproterozoic-Cambrian synsedimentary magmatism in the Central Iberian Zone (Spain): geology, petrology and geodynamic significance, Int. J. Earth Sci., 93, 897-920, 2004.

Rubio Pascual, F. J., Matas, J., and Martín Parra, L. M.: Highpressure metamorphism in the Early Variscan subduction complex of the SW Iberian Massif, Tectonophysics, 592, 187-199, 2013.

Sánchez Carretero, R., Eguíluz, L., Pascual, E., and Carracedo, M.: Ossa-Morena Zone: Igneous rocks, in: Pre-Mesozoic Geology of Iberia, edited by: Dallmeyer, R. D. and Martínez García, E., Springer, 292-313, 1990.

Sanderson, D. J. and Marchini, W. R. D.: Transpression, J. Struct. Geol., 6, 449-458, 1984

Shelley, D. and Bossière, G.: A new model for the Hercynian Orogen of Gondwanan France and Iberia, J. Struct. Geol., 22, 757776, 2000.

Silva, J. B. and Pereira, M. F.: Transcurrent continental tectonics model for the Ossa-Morena Zone Neoproterozoic-Paleozoic evolution, SW Iberian Massif, Portugal, Int. J. Earth Sci., 93, 886896, 2004.

Silva, J. B., Oliveira, J. T., and Ribeiro, A.: South Portuguese Zone, estructural outline, in: Pre-Mesozoic Geology of Iberia, edited by: Dallmeyer, R. D. and Martínez García, E., Springer, 348362, 1990. 
Simancas, J. F.: Geología de la Extremidad Oriental de la Zona Sudportuguesa, Ph. D. Thesis, Univ. de Granada, 439 pp., 1983.

Simancas, J. F.: La deformación en el sector oriental de la zona Surportuguesa, Boletín Geológico y Minero, 82, 239-268, 1986.

Simancas, J. F., Martínez Poyatos, D., Expósito, I., Azor, A., and González Lodeiro, F.: The structure of a major suture zone in the SW Iberian Massif: the Ossa-Morena/Central Iberian contact, Tectonophysics, 332, 295-308, 2001.

Simancas, J. F., Carbonell, R., González Lodeiro, F., Pérez-Estaún, A., Juhlin, C., Ayarza, P., Kashubin, A., Azor, A., Martínez Poyatos, D., Almodóvar, G. R., Pascual, E., Sáez, R., and Expósito, I.: Crustal structure of the transpressional Variscan orogen of SW Iberia: SW Iberia deep seismic reflection profile (IBERSEIS), Tectonics, 22, 1062, doi:10.1029/2002TC001479, 2003.

Simancas, J. F., Expósito, I., Azor, A., Martínez Poyatos, D., and González Lodeiro, F.: From the Cadomian orogenesis to the Early Palaeozoic Variscan rifting in Southwest Iberia, J. Iber. Geol., 30, 53-71, 2004.
Simancas, J. F., Tahiri, A., Azor, A., González Lodeiro, F., Martínez Poyatos, D., and El Hadi, H.: The tectonic frame of the VariscanAlleghanian orogen in southern Europe and northern Africa, Tectonophysics, 398, 181-198, 2005.

Stampfli, G. M. and Borel G. D.: A plate tectonic model for the Paleozoic and Mesozoic constrained by dynamic plate boundaries and restored synthetic oceanic isochrones, Earth Planet. Sc. Lett., 196, 17-33, 2002.

Teyssier, C. and Tikoff, B.: Fabric stability in oblique convergence and divergence, J. Struct. Geol., 21, 969-974, 1999.

Teyssier, C., Tikoff, B., and Markley, M.: Oblique plate motion and continental tectonics, Geology, 23, 447-450, 1995.

Tikoff, B. and Fossen, H.: Three-dimensional deformations and strain facies, J. Struct. Geol., 21, 1497-1512, 1999.

Tikoff, B. and Teyssier, C.: Strain modeling of displacementfield partitioning in transpressional orogens, J. Struct. Geol., 16, 1575-1588, 1994. 